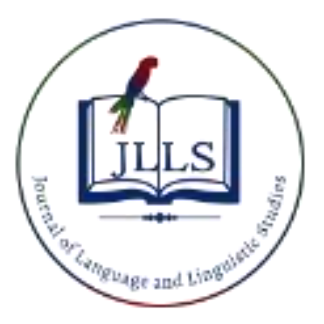

Available online at www.jlls.org

JOURNAL OF LANGUAGE AND LINGUISTIC STUDIES

ISSN: $1305-578 \mathrm{X}$

Journal of Language and Linguistic Studies, 16(2), 711-728; 2020

\title{
The acquisition of discourse-pragmatic rules for null and overt first-person subjects by Greek learners of Turkish
}

\author{
Aytaç Çeltek ${ }^{1}$ (D) \\ Kırlkkale University, Turkey \\ APA Citation: \\ Çeltek, A. (2020). The acquisition of discourse-pragmatic rules for null and overt first-person subjects by Greek learners of Turkish. Journal \\ of Language and Linguistic Studies, 16 (2), 711-728. \\ Submission Date:06/05/2020 \\ Acceptance Date:28/05/2020
}

\begin{abstract}
In Turkish, null and overt arguments do not show the same distributional properties at discourse level. There are discourse-pragmatic factors affecting this distribution (Kerslake, 1987; Ruhi, 1996; Turan, 1995; Çeltek \& Oktar, 2014; Çeltek Kaili, 2017). Previous studies suggest that the acquisition of argument realization system in second language (L2) poses a major acquisition problem for adult L2 learners, especially the properties that constrain the native use of null and overt subjects at the syntax-discourse interface are reported to cause persistent difficulty. Based on this assumption, this study investigates this problematic area in L2 acquisition from a discoursepragmatic view. More specifically, the purpose of the present study is to inspect the acquisition of the following discourse-pragmatic rules governing the use of null and overt first-person subjects in L2 Turkish oral narratives produced by first language Greek speakers: a) salient referent, $b$ ) switch focus, c) contrastive focus, d) pragmatic weight, e) epistemic parenthetical. The data were collected via three oral narrative tasks. The participants were 10 advanced L2 Turkish learners and 10 native Turkish speakers. Results obtained from the three oral narrative tasks demonstrate that advanced L2 learners of Turkish present practically no deficiency on the use of discoursepragmatic rules that govern the use of null and overt first-person subjects.
\end{abstract}

(C) 2020 JLLS and the Authors - Published by JLLS.

Keywords: adult L2; L2 Turkish; L2 acquisition of discourse-pragmatic rules; null and overt subjects; syntaxdiscourse interface

\section{Introduction}

\subsection{Literature Review}

In the field of discourse-pragmatics, argument realization phenomenon has been recently considered as component of the broader theoretical context of referential communication. As Ateş-Şen, Demir and Küntay (2016, p.153) state that referential communication is a multifaceted skill since it comprises a large number of referents, different linguistic forms, various contexts and interactants that may affect speakers' choices. Argument realization requires the choice of a certain linguistic form - a full NP, a

\footnotetext{
${ }^{1}$ Corresponding author. Tel.: +90-318 3574242

E-mail address: aytacceltek@kku.edu.tr
} 
pronoun, or null argument (i.e. zero anaphora) - to state the referent of the subject or object of the predicate. As a complex phenomenon, argument realization has been a major field of study in second language research since it stimulates a number of theoretical assertions about the relation between language typology and language acquisition process. In the relevant literature of argument realization, previous researchers have examined discourse-pragmatic features (such as salient referent/ topicality, switch focus, contrastive focus/emphasis, person, animacy, attention) across different languages, in which adult language users use in reference tracking (Givón, 1983; Prince, 1985; Chafe, 1987; Du Bois, 1987; Ariel, 1990; Gundel, Hedberg, \& Zacharski, 1993). In the past 25 years, a new standpoint on child argument realization concentrates on what conditions are operative in a child's argument choice as lexical, pronominal, or null (see Allen, Skarabela, \& Hughes, 2008 for the relevant literature).

In recent decades, a growing number of cross-linguistic studies investigate the L2 acquisition of the discursive properties of argument realization in typologically different languages, i.e. Spanish, Italian, Greek, Chinese and Japanese just to name few. It is clearly indicated in the relevant literature that there exist cross-linguistic variances in argument realization between different typologies. In languages, such as Turkish and Greek that allow null subject or null argument (pro-drop languages), the subject and, in certain contexts, the object can be omitted, whereas in languages such as German, English, French (subject prominent languages) subject and/or object omission is not usually allowed. Languages definitely are affected by syntactic, semantic, and discourse factors which allow argument omission. SLA researchers try to explore the L2 acquisition of various discourse factors that govern the realization of arguments in a particular form depending on discourse conditions. In general, the research on this issue deal mostly with theoretical evaluations and approaches to enlighten its acquisition. These studies reveal that learners show deficiencies when the use of null and overt subject depends upon certain discursive factors at the syntax-discourse interface, however if it is operated solely by syntactic factors, they do not show such deficits (Pérez-Leroux \& Glass, 1997, 1999; Serratrice, Sorace, \& Paoli, 2004; Tsimpli, Sorace, Heycock, \& Filiaci, 2004; Montrul \& Rodríguez-Louro, 2006). This indication originates from the Interface Hypothesis (Sorace, 2003) which claims that L2 learners can completely acquire narrow syntactic properties, however the interfaces where different linguistic components intermingle may be the source of particular difficulties in adult L2 acquisition (White, 2011, p.577). The hypothesis has developed over time. Recent version of this hypothesis proposes that all interfaces do not pose difficulties in the same way, and certain interfaces are more vulnerable than others (Tsimpli \& Sorace, 2006; Sorace \& Filiaci, 2006; Sorace \& Serratrice, 2009). According to the Interface Hypothesis, the syntax/discourse interface is the main source of difficulty, producing difficulties in L2 acquisition even in near native learners (Slabakova \& Ivanov, 2011, p.638). In this respect, when a second language learner of a pro-drop language does not appropriately incorporate the components of syntax and discourse, this may give rise to the overuse of overt subject forms (full NP, pronouns) (Gürel, 2016, p.338). According to Sorace \& Filiaci (2006), even near-native L2 learners may show non-native-like behavior while processing null and overt subject pronouns, the use which is mostly under the control of pragmatic conditions.

Building on the insights of the works mentioned above, the present study aims to look at the L2 acquisition of discourse-pragmatic rules that govern the argument realization phenomenon in Turkish. This study tries to find answer to the following question: Do the adult Greek speakers learning Turkish (henceforth L2ers) acquire the discourse-pragmatic rules that Turkish native speakers (henceforth NSs) depend on while using null and overt first-person subjects in Turkish oral narratives?

In order to find answer to this question, this study is organized as follows: The subsequent section aims to present an overall picture of argument realization in Turkish and Greek. Section 3 presents the argument realization phenomenon in discourse-pragmatic approach and particularly the discoursepragmatic rules that govern the use of null and overt first-person subjects in Turkish. In Section 4 the 
methodology and the procedure are presented in detail. The analyses and the results are presented in Section 5. Section 6 ends with a discussion of the main findings and suggestions for further research.

\subsubsection{Argument realization in Turkish}

Since this study deals with the $\mathrm{L} 2$ acquisition of the argument realization system of Turkish by adult Greek speakers, it is essential to look at the reference systems of both languages, namely Turkish and Greek.

As it is well known, Turkish allows both null subject and null object (Taylan, 1986; Kornfilt, 1987, 1997; Özsoy, 1987; Turan, 1995, 1998, 2000; Aygen, 2004; Öztürk, 2005; Göksel \& Kerslake, 2005; Çeltek \& Oktar, 2017; Çeltek Kaili, 2017). That is to say, in Turkish the conjugated verb shows agreement with number and person of the subject. Apart from this, there are essentially many ways to express anaphoric relationship in Turkish, and here, for the relevance with this study, out of the general reference system, the argument omission and overt expression of subjects will be explained.

Subject omission: In Turkish, the subject of a finite verb is omitted, as in (1). In (1) the personal ending of the verb ( $3^{\text {rd }}$ person plural) is co-referential with the omitted subject, either $3^{\text {rd }}$ person plural pronoun onlar 'they', or two or more proper nouns, for example Ayla, Mehmet ve Hasan 'Ayla, Mehmet and Hasan'.

(1) Şimdi git-ti-ler.

'They have just left'

Subject omission also occurs in non-finite clauses, as the subject of the noun clause in (2) and the subject of the adverbial clause in (3). In Turkish, subjects of complement clauses, relative clauses formed with $-\mathrm{DIK} /(\mathrm{y}) \mathrm{AcAK}$ and some types of adverbial clause are displayed by the appropriate possessive marker on the predicate (Özsoy, 1999, p. 238; Göksel \& Kerslake, 2005,p. 467).

(2) Ayşe [benim/Ø geldiğim]-i biliyor.

'Ayse knows that I have come'

(3) [bizim/Ø Çalışmamız] için zaman verdiler.

'They gave us extra time to study'

Genitive-marked personal pronouns expressing possessors are also omitted where matching possessive markers are present, as in (4):

(4) benim/Ø Arkadaş-ım-ı tanıyor musun?

'Do you know my friend?'

The omission is not optional when the possessor of the noun phrase and the subject of the sentence are identical, as in (5):

(5) *benim/Ø saç-Im-1 kestir-di-m.

'I had my hair cut'

Here, since the possessor of the noun phrase and the subject of the sentence are co-referential, it is not allowed to use the pronoun benim to modify saçım.

Object omission: In Turkish, both direct objects and other oblique objects can be omitted in coordinate constructions conjoined with conjunctions such as ve 'and', ya da 'or', ne ... ne de 'neither. .. nor', hem.... hem 'both... and' etc. as in (6).

(6) Hayat'li okuldan aldım ve onu $/$ / $\varnothing_{i}$ eve getirdim. (direct object)

'(I) picked Hayat up from the school and (I) brought her to the house. 
There is a constraint for the omission of the second or subsequent occurrence of a complement requiring a different case marker from that used on its first occurrence. If this is the case, instead of an omission of the object, the overt pronoun is preferred with the appropriate case marker, as in (7), which is taken from the naturally occurring data used in Çeltek Kaili (2017):

(7) ...rahat bırakın şu adamı. Eğer böyle bir durum varsa, $\emptyset_{\mathrm{i}}$ atın gitsin. Şimdi onai niye bu kadar eziyet ediyorsunuz yaa?

'Leave this man alone. If this is the case, send him away. Now, why do you mistreat him so hard?'

In (7) şu adamı 'this man`, which is a full NP, is in the accusative case when it first occurs, in the second mention of the same referent, it is simply omitted since the verb at- 'to throw` requires accusative case marked noun phrase. In the third mention of the same referent, the main verb eziyet et- 'to torture' requires a dative-marked noun phrase, therefore overt pronoun is used in the sentence.

Object omission emerges also in question /answer pairs when the null object is evoked in the question part, as in (8):

(8) - Sen hiç izledin mi korsan ${ }_{i}$ ?

- Øi İzlemiş̧imdir.

'- Have you ever watched a bootleg dvd?

- I think I've watched once.'

Null objects can also occur without having an antecedent in discourse. In this case, the context of the situation, in which the utterance is produced, makes the antecedent of the null object accessible, as in (9):

(9) [konuşucu, odada oynayan küçük kızı göstererek]

- Annesi Ø buraktı. Saat beşte gelip Ø alacak.

[the speaker pointing at the little girl playing in the room]

- Her mother left [her]. She'll come and pick [her] up at 5 o'clock.

It should be noted that overt expression and omission of referents do not have the same distributional properties in Turkish, especially, when larger discourse contexts are considered. Specifically, the use of null and overt arguments in discourse is governed by certain pragmatic and syntactic constraints (Enç, 1986; Taylan, 1986; Gürel, 2006; Haznedar, 2010). The discourse-pragmatic rules that speakers track for argument omission are more multifaceted than grammars and textbooks suggest. Actually, textbooks often imply that argument omission is a case of "optional use", accordingly one can support the idea of optionality of argument omission only by looking at isolated sentences as in (10):

(10) a. Ben kütüphane-ye gid-iyor-um 'I am going to the library'

b. Ø Kütüphane-ye gid-iyor-um '(I) am going to the library'

Without taking into consideration the discourse context in which these discourse fragments occur, one surely would explain the occurrence of argument omission in (10b) by the idea of optionality. In parallel, since there is verbal agreement for subjects, one would describe the use overt subject pronouns as in (10a) as redundant. However, this is not the case for Turkish discourse structure. Therefore, this issue will be held in detail in Section 3, in terms of the discourse-pragmatic rules that govern argument realization in Turkish.

Although literature on discourse-pragmatic factors that govern argument realization in Turkish does not present a complete description of the issue, there are certain key works that are worth mentioning here. Numerous studies on null and overt pronouns in Turkish have been carried out from a generative perspective, which tend to be theory driven, focusing on the occurrence of overt subjects versus null subjects, which is constrained by internal linguistic properties (e.g. Enç, 1986; Taylan, 1986; Özsoy, 
1992, 1987). As stated also in Azar, Backus and Özyürek (2016, p. 1296) these cited studies do not use empirical data to support their claims. Consequently, the variable use of overt subjects and null arguments in reference tracking in Turkish discourse and also the forms used in coding maintained and re-introduced referents have not been clearly defined yet in the related literature.

Other researchers (Kerslake, 1987; Ruhi, 1996; Turan, 1995; Çeltek \& Oktar, 2004, 2014) have addressed argument realization in Turkish from a discourse-pragmatic perspective, explaining how factors including referent accessibility, topicalization and the hierarchical structure of discourse stimulate the argument realization phenomenon. All of these studies have a common implication that the discourse principles govern the argument realization in Turkish. Although prior studies have indicated the need to take into account discourse-pragmatic factors in governing null vs. overt argument use in native Turkish, to the best of my knowledge, there is no study that examines the relation between discourse structure and L2 acquisition of Turkish argument realization phenomenon. By investigating this phenomenon from a discourse-pragmatic perspective, the present study aims to fill this gap in the field.

On the other hand, there are also some studies which have investigated the argument realization phenomenon in the L2 acquisition context, but not from a discourse-pragmatic perspective. Gürel (2006), based on the UG framework, investigates L2 acquisition of null and overt subject use and their binding property in terms of L1 transfer in end-state learners. In her study, she suggests when an L2 learner could totally govern discourse constraints (i.e., when to use null subject or overt subject pronoun) it means that L2 learner successfully acquires the null subject parameter. The results of her study showed that English learners of Turkish as an L2 acquired the appropriate use of null and overt subjects though they have difficulties in managing binding properties of one particular overt pronoun in Turkish since they transfer L1 syntactic options regarding the definition of governing categories. Bulut and Can (2000) adopt the Principles and Parameters framework of UG, proposed by Chomsky (1982). They test the three general hypotheses (no access, indirect access, and direct access) relating to the null subject parameter. The results show that English learners of Turkish do not apply the non-pro-drop properties of English into Turkish. They suggest that transfer errors may be due to the mismatch between L1 and $\mathrm{L} 2$; but if the $\mathrm{L} 2$ value is less marked than the $\mathrm{L} 1$ value, learners easily switch from the marked mother tongue value to the unmarked $\mathrm{L} 2$ value.

Despite the lack of studies on the L2 acquisition of argument realization phenomenon in Turkish, there are comprehensive studies which explore the null subject phenomenon in L1 and bilingual acquisition. Haznedar (2010) cross-linguistically compares the subject realization phenomenon in two children, one is bilingual in Turkish English, and the other is monolingual in Turkish. She suggests that the subject realization in Turkish, a null subject language, is clearly related with the pragmatics-syntax interface of the grammar and for that reason, cross-linguistic interference is most likely to occur in bilingual acquisition. The findings of the study show that the rate of the bilingual child's use of overt subjects in pragmatically inappropriate contexts is 10 times higher than that of the monolingual child. Similarly, Altan (2013) analyzes the L1 acquisition of pro-drop among children between the ages 2;0$4 ; 8$ acquiring Turkish as a native language. The analysis of the data reveals that children from all age groups omit the subject pronouns, especially in verbal sentences. The data from children in the smallest age group reveals that they tend to overgeneralize the pro-drop phenomenon, and this causes ambiguity in some cases. Altan (2013) concludes that the rate of pro-drop decreases with age and children tend to use it more correctly.

\subsubsection{Argument realization in Greek}

As for the Greek referential system, like in Turkish, agreement features morphologically bring about the subject omission of a finite verb, as in (11). 
(11) Éfi

'(They) left suddenly'

In (12) the personal ending of the verb (third-person plural) is co-referential with the omitted subject of the verb (Holton, Mackridge, Philippaki-Warburton, \& Spyropoulos, 2012, p.576).

According to Holton et al. (2012, p.576), an actual pronoun is only used as the subject of a verb if it is emphatic or contrastive, as in example (12):

(12) Ekeínoi éfíyan ksafnika enw emeís meíname

'They suddenly left while we stayed'

Like Turkish, Greek also allows postverbal subjects as illustrated in (13):

(13) Éfi $\gamma$ o Giannis

* Left John.

'John left.'

As a feature not found in Turkish, there are also clitic (weak) pronouns in Greek. The weak pronouns act as the object of a verb. When they are direct object, they are realized in the accusative case (to in (14)), when they are the indirect object of a verb, they are realized in the genitive case (mou in (14)) (Holton et al., 2012, p.386). :

(14) Mou to édoses

'(You) gave it to me'

In Greek, non-specific object arguments can be omitted. Null objects are possible both with an indefinite antecedent in discourse and with no antecedent available. In (15), NP-ellipsis is exemplified (Tsimpli \& Papadopoulou, 2006, p.1599):

(15) A: Éfere o Andreas merika vivlia?

B: $\mathrm{Ne},(*$ ta) éfere.

'A: Has Andreas brought any books?'

'B: Yes, he did.'

The use of object clitic (ta) in (15) causes ungrammaticality. In (16a) and (16b), null objects occur with indefinite reference and no antecedent:

(16) a. Kathos dhjavaza, htipise to tilefono.

"While I was reading, the phone rang."

b. To kolibi kurazi.

"Swimming makes (you) tired."

The occurrence of null objects in (15) and (16) have an indefinite, non-specific reading (Tsimpli \& Papadopoulou, 2006, p.1599).

The following section discusses discourse-pragmatic factors that govern the argument realization phenomenon in Turkish.

\subsubsection{Discourse-pragmatics of argument realization}

The present study examines the discourse-pragmatic aspects of the acquisition of argument omission and overt argument expression which has been generally overlooked by TAFL researchers. In the last forty years, research on discourse and grammar have revealed clear correlations between discoursepragmatic factors and the form of reference tracking device selected. Some investigated discoursepragmatic factors that determine the use of appropriate reference form in context are newness, number 
of other potential competitor referents, number of utterances that the referent persists, topicality, presence in the physical context and animacy (Allen et al., 2008, p. 102).

Depending on some or all of these features, various researchers have developed scales or hierarchies to indicate the correlation between reference tracking device and the accessibility degree of referent (Ariel, 1990; Givón, 1983; Gundel et al., 1993; Prince, 1985). For example, according to Givón, who investigated the effect of topicality, "the more continuous/predictable is the topic/subject/referent NP, the less overt expression it needs to receive" $(1983$, p.67). In general, these various scales propose in common that a referent has a high accessibility when it is recently mentioned in discourse. Other conditions that affect the high accessibility of a referent are the absence of potential competitor referent, the topichood of current discourse and persistency after the first mention and being the focus of attention of the interlocutors. In contrast, low accessible referents are the ones that are newly mentioned, with several competitors, not persistent after initial mention, not the topic of discourse or focus of attention (Allen et al., 2008, p.102).

These associations between referent accessibility and argument realization have been supported in many studies over an extensive variety of languages of different typologies. The most effective factors on argument omission-both subjects and objects- are topic continuity, in focus status, antecedent saliency, aboutness (Givón, 1983; Gundel et al., 1993; Ariel, 1990; Reinhart, 1982). The use of overt subject pronouns is also governed by various discourse-pragmatic factors, namely switch focus and contrastive focus (Quesada, 2015, pp. 180-182). The next chapter presents these discourse-pragmatic factors that govern the use of null and overt subjects in Turkish discourse.

\subsubsection{Discourse-pragmatic rules that govern first-person null and overt subjects}

In this experimental study, which was conducted with L2ers and NSs, five discourse-pragmatic rules that affect the choice between null and overt subjects were investigated. In the following sections, these rules that are assumed to control the use of null and overt first-person subjects will be explained in detail.

1. Referent Saliency refers accessibility or prominence of a referent which is in focus in the discourse. Over the past years, researchers evidently found out that the speaker's preferences of forms of reference are affected to a large extent by the salience of the referent (e.g. Ariel, 1990; Du Bois, 1987; Givón, 1983; Gundel et al., 1993). At any point in discourse, the salient entity is the one that the discourse is about and is predicted most likely to be referred to by different referent tracking devices. Typically, in Turkish, this is realized by the use of null subjects and null objects. NSs use a null subject or object whenever the referent is in focus.

2. Switch focus refers to the native speakers' tendency to select an overt subject pronoun when there is a need to shift the focus from one salient referent to the other one which become also salient in the particular piece of discourse.

3. Contrastive focus occurs when multiple referents present in discourse. In this instance, an overt pronoun is used in contrast to another referent in the discourse.

4. Pragmatic weight refers to a speaker's appeal to intensify their contribution in an utterance whether it is an argument or a statement of belief (Quesada, 2015, p.179). According to Davidson (1996), speakers use overt subject pronouns when they commit themselves to their utterances they produce. Since theories of emphatic use or contrastive use of overt pronouns do not suffice to make generalizations about this kind of pronoun appearance, Davidson expects that the term pragmatic weight which is used for pragmatic use of subject pronouns in spoken Spanish can be an explanation for this kind of use of overt subjects in other prodrop languages (1996, pp.564-565). In the data of the present study, it is distinctly verified that Turkish native speakers use this strategy. That is to say, Turkish native speakers use overt 
subject pronouns with verbs of opinion, belief, claiming (inanmak 'to believe', düşünmek 'to think'), emotion (hissetmek 'to feel', istemek 'to want'), or knowledge (bilmek 'to know').

5. First-person epistemic parentheticals (the term as used by Brinton, 1996) are generally used in discourse when the speaker is not completely sure in expressing a matter. They are optional pragmatic markers occuring frequently and express the speakers' degree of certainty. According to Davidson, verbs of knowing and verbs of seeing or watching are used to produce more conceptual meanings and give information about speaker's position on an utterance (1996, p. 557). These types of verbs are inclined to grammaticalization by losing their truth-functional content and become metapragmatic mentions on speaker's utterances. Turkish expressions such as ne bileyim, bilmiyorum ('I don't know') or diyorum ('I say' or 'I mean') occur with null pronouns for first-person.

By analyzing oral narratives from NSs and L2ers, this study tries to validate if native speakers apply these rules for the use of first-person subject and investigates if L2ers acquire the discourse-pragmatic rules which are not typically part of foreign language education. In the next section the experimental study is presented in detail.

\section{Method}

\subsection{The present study}

As stated earlier, the aim of this study is to reveal the acquisition of discourse factors, which govern the emergence of argument omission, by adult Greek L2 learners of Turkish. The analysis of the reference systems of Turkish and Greek in terms of argument omission and overt expression shows that both languages allow null arguments. There may be certain discourse-pragmatic differences in argument realization, but any comparison of these differences between the two languages would be out of the scope of this study. For that reason, this study does not deal with the discourse-pragmatic factors that adult Greek speakers consider for argument realization in their L1, namely Greek. This study focuses on the discourse-pragmatic rules that Turkish native speakers follow in referencing first-person subjects when they produce narratives. Based on the literature review, five pragmatic rules for native speaker use of null and overt subjects have been proposed: salient referent, switch focus, contrastive focus, pragmatic weight, and epistemic parenthetical (Davidson, 1996; Quesada \& Blackwell, 2009). The data obtained from the narratives of native Turkish speakers and of Greek L2 learners of Turkish are examined and their use of null and overt subjects are compared in light of these rules.

\subsection{Participants}

The data used for this study were collected from 10 native Greek L2 learners of Turkish and 10 NSs of Turkish. The age range of L2ers is between 28 and 50 (mean age 37,6). The control group of this study comprises $10 \mathrm{NSs}$ (mean age 35,2). For the integrity of our results, the following social variables were homogenized as much as possible: (i) both the L2 participants and the control group participants have at least a university degree, (ii) the participants have living experience in Turkey at least for 2 months, maximum 10 years. The L2 participants' Turkish proficiency levels varied between B2 to C2 on the basis of the Common European Framework of Reference (CEFR, 2014). L2 participants' profile can be seen in Table 1 . 
Table 1. L2 participants' profile

\begin{tabular}{llll}
\hline Participant & Age & Gender & Education \\
\hline $\mathbf{1}$ & 41 & Male & $\mathrm{PhD}$ \\
\hline $\mathbf{2}$ & 30 & Female & $\mathrm{PhD}$ cand. \\
\hline $\mathbf{3}$ & 47 & Female & MA \\
\hline $\mathbf{4}$ & 42 & Male & $\mathrm{PhD}$ \\
\hline $\mathbf{5}$ & 32 & Female & $\mathrm{MA}$ \\
\hline $\mathbf{6}$ & 28 & Female & MA \\
\hline $\mathbf{7}$ & 44 & Male & $\mathrm{PhD}$ \\
\hline $\mathbf{8}$ & 31 & Male & BA \\
\hline $\mathbf{9}$ & 31 & Female & MA cand. \\
\hline $\mathbf{1 0}$ & 50 & Female & MA \\
\hline
\end{tabular}

\subsection{Data collection procedures}

The analysis of this study is based on oral narrative data coming from three oral narrative tasks: a description of a person, a story telling and a narrative of the future plans of the participants. These sources of information provided the use of argument omission circumstances isolated from recordings of naturally occurring discourse produced by our participants. All the narrative tasks were conducted by the author. In the first narrative task (Taskl) the participants were asked to tell about the most important person in their lives. The participants were asked to provide as much detail about that special person as they can.

The second source of data was obtained via story telling (Task 2). In this task, the participants narrated the fairy tale Little Red Riding Hood in Turkish in an unrestricted manner. The participants were showed only the pictures taken from the book (Lomba, 2006) and they were asked to tell the story by the help of these pictures, including as much detail as possible. The story involves two protagonists (the girl and the wolf) who act in turns: in the narrative, the participants had to introduce both protagonists and the other characters of the story (the mother, the grandmother, the woodcutter), maintain each reference while avoiding ambiguity but also shift reference from one protagonist or character to the other. This makes this task appropriate for a study of argument realization strategies.

The third source of data was obtained via personal narrative which concerns the participant's professional plans for the future. The participants were asked to give details about their plans for their academic or professional careers in the future.

It took 15-30 minutes to complete the requested tasks for each participant. The narratives were recorded in a place where the interviewer and the participant present. All the instructions about the tasks were given in Turkish. When needed, the interviewer provided some Turkish vocabulary related to the topic of the task to the Greek participants. The narratives were subsequently transcribed using conventional orthography.

\subsection{Data Analysis}

For this study, in total 60 oral narratives -30 from L2 participants and 30 from native speaker participants- were examined to determine to what extent the L2 group was self-conscious by the discourse-pragmatic constraints on the use of null and overt first-person subject. Once all the tasks were completed, each first-person singular reference in the discourse was identified based on one of the five discourse-pragmatic factors. The identification each reference context was accomplished in the following manner: 
1. salient referent, encoded by a null subject, refers to the one which is prominent and in focus of attention in the discourse, as in (17),

(17) ben şöyle birşey hayal ediyorum, yani aynı bölümde Ø İbranice okutmak istiyorum

'I imagine something like this, namely, (I) want to teach Hebrew in the same department'

Here, the subject $\varnothing$ of istiyorum 'would like' and the subject ben 'I' of hayal ediyorum 'imagine' are co-referential and these subjects are prominent in this particular discourse.

2. switch focus occurs if a referent is other than the previous one in focus in the prior discourse. In this context, subject is encoded by overt first-person subject pronoun ben 'I', as in (18).

(18) Yaren Denizli'de zorunlu hizmet olduğu için daha muhtemelen beş ya da altı sene daha çok orda kalması gerektiği için ben Türkiye'de muhtemelen özel bir Üniversitesi'nde bir iş bulmayı düşünüyorum.

'Since Denizli is a mandatory service for Yaren and since she is more likely to remain there for five or six years more, I think I probably get a job in a private university in Turkey.'

3. In parallel constructions, contrastive focus refers to the referent which is the marked for contrast and encoded by overt pronoun, as in (19).

(19) Erkek kardeşim benden üç yaş küçük, şu anda uzağız birbirimizden, o Yunanistan'da oturuyor, ben Türkiye'de oturuyorum.

'My brother is three years younger than me; we are far from each other at the moment, he lives in Greece, I live in Turkey.'

4. pragmatic weight is identified by overt first-person subject pronouns which increase speakers' commitment to their utterance. This use occurs with the verbs of knowing, believing, feeling or judging as in (20).

(20) Ø yardımcı doçent olduktan sonra, yani Ø kadro bulursam, başka bir yerde Ø istediğim bir şehirde, Ø oralara geçebilirim biraz daha batıya, $\varnothing$ geçemezsem $\varnothing$ doçentliği zorlarım ama ben bu mesleği memuriyet olarak görmediğim için ...

'After being an assistant professor, I mean [I] can go to another place, to a city that [I] want, if [I] find a position. However, since I don't treat this profession as a civil service....'

In (20), although the referent is salient in the ongoing discourse and encoded by null subject in the first three sentences, the participant, subsequently, codes himself with an overt pronoun ben 'I', because the verb (olarak) görmek 'treat as', a verb of opinion, needs a pragmatic weight.

5. When null subjects of the verbs of knowing, speaking, seeing are used as evaluative statements about the speakers' utterances, they are marked as epistemic parenthetical.

(21)zaten daha sonra $\varnothing$ bilmiyorum o ilgisi aile hayatından mıdır yoksa çalıştığı iş ortamı orada işte kendisinden daha az eğitimli işte birazcık daha böyle sakil insanlarla geçirdiği vakitten midir nedir biraz o böyle şeyini dine doğru döndürdü,

'Anyway, later, [I] do not know, if the reason is his family life, or the business environment in which he works, where he was with unappealing people who were less educated than himself, he turned his attention to religion'

In this paper, I focus solely on the use of null and overt subjects and I will not consider other errors of the participants. In the next section, the findings of the analyses are presented.

\section{Results and Discussion}

In the analysis, the discourse pragmatic rules were used for the classification of each referential context. The data obtained were first analyzed in terms of the use of null and overt first-person subject 
per group. In Table 2 the percentages given are the total results for the tasks per first-person referential contexts. The results show that the use of null first-person subject in both groups outnumber the use of overt first-person subject use. Although the total number of first-person referential contexts is slightly less in L2ers, the percentages of the distribution between null and overt subjects in both groups are almost equivalent.

Table 2. Null and overt first-person subject distribution

\begin{tabular}{lccc}
\hline & $\begin{array}{c}\text { Overt first-person } \\
\text { subject } \\
\%\end{array}$ & $\begin{array}{c}\text { Null first-person } \\
\text { subject }\end{array}$ & $\begin{array}{c}\text { first-person referential } \\
\text { contexts } \\
\text { no. }\end{array}$ \\
\hline L2ers & 15 & 85 & 268 \\
\hline NSs & 16 & 84 & 324 \\
\hline
\end{tabular}

As displayed in Table 2, the overall results show that null and overt first-person subjects are used in different referential contexts. In both L2ers and the NSs, the most frequently used form for encoding first-person subject references is null subject (\% 85 and \% 84). Overt first-person subject use in both groups is significantly lower. These results show us that in terms of the tasks conducted in this study, there seems to be consistency between the NSs and the L2ers in their reference form preference for firstperson subjects.

The results obtained from the NSs indicate that this group apply all the discourse-pragmatic rules for the use of null and overt first-person subjects as expected. The results can be seen in Table 3 .

Table 3. Null and overt first-person subject distribution in the native speaker group.

\begin{tabular}{lccc}
\hline & Overt & Null & first-person referential contexts \\
& $\%$ & $\%$ & no. \\
\hline Salient referent & 0 & 100 & 228 \\
\hline Switch focus & 100 & 0 & 16 \\
\hline Contrastive focus & 100 & 0 & 12 \\
\hline Pragmatic weight & 100 & 0 & 23 \\
\hline Epistemic parenthetical & 0 & 100 & 45 \\
\hline Total number & & & 324 \\
\hline
\end{tabular}

As discussed earlier, null and overt use of referents do not have the same distributional properties and are not in free variation in Turkish. The results obtained from the NSs confirm this statement within the framework of the five discourse-pragmatic rules. The NSs in this study choose null subjects for salient referents and for epistemic parentheticals in $\% 100$ of the contexts, while overt first-person subject pronouns are selected for switch focus, contrastive focus and for pragmatic weight.

Table 4 presents the distribution of null and overt first-person use of L2ers across the discoursepragmatic rules.

Table 4. Null and overt first-person subject distribution in L2ers

\begin{tabular}{lccc}
\hline & $\begin{array}{c}\text { Overt } \\
\%\end{array}$ & $\begin{array}{c}\text { Null } \\
\%\end{array}$ & $\begin{array}{c}\text { first-person referential } \\
\text { contexts } \\
\text { no. }\end{array}$ \\
\hline Salient referent & 0 & 100 & 153 \\
\hline Switch focus & 86 & 14 & 14 \\
\hline Contrastive focus & 100 & 0 & 6 \\
\hline Pragmatic weight & 100 & 0 & 22 \\
\hline Epistemic parenthetical & 0 & 100 & 73 \\
\hline Total number & & & 268 \\
\hline
\end{tabular}


As the data indicate, L2ers prefer null subjects for salient referents as in (22) and for epistemic parentheticals as in (23) in \% 100 of the contexts.

(22) Ben de Türkçe öğretmeye başladım son 7 yıldır o işi Ø yapıyorum fakat Türkçe artık işim oldu yine de Ø seviyorum fakat o kadar keyifli Ø çalışmıyorum

'I have been teaching Turkish for the last 7 years. [I] am doing this job, but Turkish is my business now. [I] love [it] anyway, but [I] do not enjoy it so much'

In the opening of this particular discourse, the L2er encodes himself with an overt subject pronoun which is identified as a pragmatic weight, in the subsequent discourse, though, he encodes himself with a null subject because he considers himself as the salient referent in that part.

(23) [kırmızı başlıklı kız] sonunda ninesinin evine gelmiş kapıyı çalınca kurt ninesinin sesiyle cevap vermiş ve içeriye girmiş ondan sonra kurt mu Ø diyeyim, Ø bilmiyom yani kurdun gözlerini çok merak etmiş...

'[The little red riding hood] finally came to the grandmother's house, when she knocked the door, the wolf responded with the voice of the grandmother, and then [she] went in. After that, shall [I] say the wolf, [I] do not know, so she was curious about the wolf's eyes very much...'

In (23), the L2er is telling the fairy tale, and he, himself, is not the salient referent in this discourse. However, in this part of the discourse, when the speaker demonstrates an evaluation of his own utterance, which is an epistemic parenthetical, he encodes himself with a null subject of the verbs demek 'say' and bilmek 'know'. As stated earlier, the use of epistemic parentheticals does not place a referent in a focused position.

According to Brinton (1996), in narrative, epistemic parentheticals "are attached to propositions expressing inexactness concerning time, space, and even plot details, to the narrator's external evaluations, and to meta comments on the telling of the tale". In this sense, this kind of use of null subjects as epistemic parentheticals are high in number in most of the fairy tale narratives (Task 2) of the L2ers, as shown in Table 5.

Table 5. Epistemic parentheticals in the L2 participants' Task 2

\begin{tabular}{cccc}
\hline & $\begin{array}{c}\text { Epistemic parenthetical } \\
\text { in Task 2 }\end{array}$ & $\begin{array}{c}\text { Epistemic } \\
\text { parenthetical in Tasks 1-3 }\end{array}$ & $\begin{array}{c}\text { Epistemic } \\
\text { parentheticals in total }\end{array}$ \\
\hline$\%$ & 33 & 40 & 73 \\
\hline
\end{tabular}

In Table 6 which shows epistemic parentheticals in the NSs' Task 2, it can be clearly seen that the NSs used epistemic parentheticals significantly less in Task 2.

Table 6. Epistemic parentheticals in the NSs' Task 2

\begin{tabular}{cccc}
\hline & $\begin{array}{c}\text { Epistemic parenthetical } \\
\text { in Task 2 }\end{array}$ & $\begin{array}{c}\text { Epistemic } \\
\text { parenthetical in Task 1-3 }\end{array}$ & $\begin{array}{c}\text { Epistemic } \\
\text { parentheticals in total }\end{array}$ \\
\hline$\%$ & 8 & 37 & 45 \\
\hline
\end{tabular}

When we compare the results in Table 6 with the results in Table 5, there is a noticeable difference between the two groups as far as the use of epistemic parentheticals is concerned as shown in Table 7 . 
Table 7. Comparison of the use of epistemic parentheticals in Task 2.

\begin{tabular}{lcc}
\hline & Epistemic parenthetical in Task 2 & $\begin{array}{c}\text { Epistemic parentheticals in } \\
\text { total }\end{array}$ \\
\hline NSs & $8(\% 18)$ & 73 \\
\hline L2ers & $33(\% 45)$ & 45 \\
\hline
\end{tabular}

As stated earlier, in narratives the use of epistemic parentheticals demonstrates the uncertainty of the speaker about the information. As Brinton points out (1996), first-person epistemic parentheticals are positioned to the addressee. While NSs take the full responsibility of information, L2ers did not feel confident about telling the tale correctly, consequently they employ epistemic parentheticals in Task 2 more frequently than NSs.

As for the overt first-person subject use in L2ers, Table 4 shows that L2ers prefer overt subjects both for contrastive focus as in (24) and for pragmatic weight as in (25) in \%100 of the relevant referential contexts.

(24) ...ela gözlü, başka ne, korku filmleri çok seviyor, ben onlardan çok korkuyorum.

'[he] is hazel-eyed, what else, [he] likes horror movies, I am very scared of them.'

In (24) the speaker is describing her little brother and in this particular discourse she mentions her brother's and her opposing like. The brother is encoded with a null subject, whereas the speaker encodes herself with an overt pronoun which indicates the opposition to the other.

(25) Ø 2014 çok zor bir dönem geçirdim burda hem de şeyde bireysel tecrübeler konusunda hem de iş konusunda böyle bi şeydi ben istiyordum gerçekten Ankara'dan ve Türkiye'den ayrılmak.

'[I] had a difficult time here in 2014 both on individual experiences and on business I really wanted to leave Ankara and Turkey.'

In (25) the speaker is describing the most important person in his life, but in this particular discourse, he talks about himself first. In the opening, he encodes himself with a null subject. Although there is no other competitor referent in the linguistic context of the narrative, nor is there a switch focus or contrastive focus contexts, the speaker uses overt first-person subject pronoun to encode himself where he is the only salient referent. As discussed before, this kind of usage of overt first-person subject pronoun can be explained by the term pragmatic weight which indicates the speaker's greater personal involvement or commitment to an utterance.

In switch focus contexts, however, L2ers manifest \% 14 null subject preference in contexts which require overt subject use which is exemplified in (26).

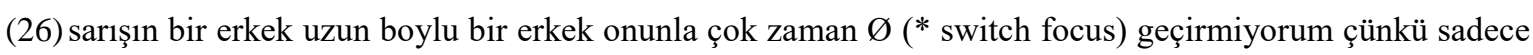
bilgisayarda oynuyor başka bir şey yapmak istemiyor

'(he) is blond, he is tall, (I) don't spend much time with him because (he) just plays computer games and does not want to do anything else'

In (26), the L2er is talking about the most important person in her life, her younger brother. Since the brother is the salient referent in this particular discourse, the speaker encodes him with null subject. However, once she switches the focus of attention to herself, she, again, prefer null first-person subject, which is not expected. Although this kind of usage violates the use of null subject rule here, the L2ers do not manifest such violations frequently as far as the data of this study is concerned. 


\section{Conclusions}

This study opens a way to understand the relationship between discourse structure, specifically the referential system and the acquisition of Turkish as second language. The results of the analysis of this study are based on that the use of null and overt first-person subject in Turkish oral narratives is governed by certain discourse-pragmatic rules. The data reveal that L2 learners appropriately apply these rules into the target language grammar. The criteria for evaluating the appropriateness come from the data of the native speaker. As predicted forms for native speakers, the learners prefer null subjects to encode salient references, however, choose overt subject pronouns for contrastive focus contexts. Still, in switch focus contexts, overt subject use displays some difficulty.

Although the present study was not conducted to test the validity of the Interface Hypothesis, it can be stated that the results obtained from the limited data of this study do not confirm the assumptions of the hypothesis. On the contrary to the assumptions of the hypothesis, in this study, the L2 participants who are also native speakers of a pro-drop language and who started to learn Turkish as a foreign language after their 20s display a native-like behavior in terms of applying the discourse-pragmatic rules that constrain the use of null and overt first-person subject when producing narratives. The success in exhibiting native-like behavior can be attributed to the proficiency level of the L2 participants. A similar study is required to be conducted with lower-level second language learners both to compare the results with those of this study and to examine the accuracy of the predictions of the interface hypothesis.

The other person references in the data were not analyzed for this study. Studying the person category individually presents the variations among first, second, and third-person forms, for instance first-person and second-person subjects are not referred to by using lexical NPs. Thus, focusing on only the realization of first-person subject in narratives provides us an overview of discourse-pragmatic rules that restrict the use of null and overt first-person subjects in native data and also gives us an understanding on handling of this issue in L2 acquisition. In the data of this study, as expected, it is observed that the discourse pragmatic rules for other person reference realization are violated in certain discourse-pragmatic conditions. The possible motivations for these violations will be held in another study and the results will be compared qualitatively to each other.

Although the extent of the this study is limited to the exploration of the acquisition of the discoursepragmatic rules in terms of first-person subjects, it is a good starting point for further research on the acquisition of discourse-pragmatic rules governing the whole reference-tracking system of Turkish. Although it is a small-scale research, the present study draws attention to potentially problematic area especially for L2 learners of lower proficiency. This study also contributes to develop more effective teaching programs for teaching referential system in discourse, i.e. how to use null and overt arguments depending on context and co-text. Discourse-based teaching materials, course design and content, teaching procedures have an indisputable importance to succeed in making learners focus on meaning and real communication and practicing language within larger meaningful contexts.

\section{Ethics Committee Approval}

The author(s) confirm(s) that the study does not need ethics committee approval according to the research integrity rules in their country (Date of Confirmation: May 06, 2020). 


\section{References}

Allen, S.E.M., Skarabela, B., \& Hughes, M. (2008). Using corpora to examine discourse effects in syntax. In H. Behrens (Ed.), Corpora in language acquisition research: Finding structure in data (pp. 99-137). Amsterdam: John Benjamins Publishing Company.

Altan, A. (2013). Acquisition of a Null Subject Language. Dil Dergisi, 161, 5-23.

Ariel, M. (1990). Accessing Noun-Phrase Antecedents. London: Routledge.

Ateş-Şen, A.B., Demir, Ö.E., \& Küntay, A.C. (2016). Children's referential choices in Turkish: Experimentally elicited and conversationally occasioned determinants. In B. Haznedar \& N. Ketrez (Eds.), The Acquisition of Turkish in Childhood (TiLAR Series) (pp. 153-175). Amsterdam: John Benjamins.

Aygen, G. (2004). Finiteness, Case and Clausal Architecture, MIT Occasional Papers in Linguistics 23. Cambridge, MA: MIT Press.

Azar, Z., Backus, A., \& Özyürek, A. (2016). Pragmatic relativity: Gender and context affect the use of personal pronouns in discourse differentially across languages. In A. Papafragou, D. Grodner, D. Mirman \& J. Trueswell (Eds.), Proceedings of the 38th Annual Meeting of the Cognitive Science Society (CogSci 2016) (pp. 1295-1300). Austin, TX: Cognitive Science Society.

Bulut, T., \& Can, C. (2000). Acquiring a Pro-drop Language. Dil Dergisi, 88, 54-60.

Brinton, L. J. (1996). Pragmatic Markers in English: Grammaticalization and Discourse Functions. De Gruyter Mouton.

Chafe, W. (1987). Cognitive constraints and information flow. In R. Tomlin (Ed.), Coherence and grounding in discourse (pp. 21-51). Amsterdam: John Benjamins Publishing Company.

Çeltek Kaili, A. (2017). Türkçe sözlü söylemde boş nesne [Null objects in Turkish spoken discourse]. In N. Kansu-Yetkiner \& M. Şahin (Eds.), Dilbilim Çeviribilim Yazıları: Prof. Dr. Lütfiye Oktar'a Armağan (pp. 67-79). Ankara: Anı Yayınc1lı. ISBN: 978-605-170-157-8

Çeltek, A., \& Oktar, L. (2004). Türkçe sözlü söylemde artgönderim örüntüleri [Anaphoric patterns in Turkish spoken discourse]. Dilbilim Araştırmaları, 1-13.

Çeltek, A., \& Oktar, L. (2014). Türkçede boş artgönderim ve söylem atlama [Zero anaphora and discourse pop in Turkish]. Dilbilim Araştırmaları, 1(1), 59-79. ISSN: 1300-8552

Çeltek, A., \& Oktar, L. (2107). Türkçe söylemde boş nesne [Null objects in Turkish discourse]. In B. Makaroğlu, İ. P. Bekar \& E. Arıca Akkök (Eds.), 30. Ulusal Dilbilim Kurultayı Bildirileri (pp. 125132). Ankara: Dilbilim Derneği Yayınları.

Davidson, B. (1996). "Pragmatic weight" and Spanish subject pronouns: the pragmatic and discourse uses of "tú" and "yo" in spoken Madrid Spanish. Journal of Pragmatics, 26, 543-565.

Du Bois, J. W. (1987). The discourse basis of ergativity. Language, 64, 805-855.

Enç, M. (1986). Topic Switching and Pronominal Subjects in Turkish. In D. Slobin \& K. Zimmer (Eds.), Studies in Turkish Linguistics (pp. 195-208). Amsterdam: John Benjamins Publishing Company.

Givón, T. (1983). Topic continuity in discourse: the functional domain of switch-reference. In J. Haiman \& P. Munro (Eds.) Switch reference and Universal Grammar (pp. 51-82). Amsterdam: John Benjamins Publishing Company.

Göksel, A., \& Kerslake, C. (2005). Turkish: A Comprehensive Grammar. London: Routledge. 
Gundel, J., Hedberg, N., \& Zacharski, R. (1993). Cognitive Status and the form of Referring Expressions in Discourse. Language, 69, 274-307.

Gürel, A. (2006). L2 acquisition of pragmatic and syntactic constraints in the use of overt and null subject pronouns. In R. Slabakova, P. Prévost \& S. Montrul (Eds.), Inquiries in Linguistic Development (pp. 259-282). Amsterdam: John Benjamins Publishing Company.

Gürel, A. (2016). Conclusion: Emerging issues in the acquisition of L2 Turkish and pedagogical considerations. In A. Gürel (Eds.), Second Language Acquisition of Turkish (pp. 333-346). Amsterdam: John Benjamins Publishing Company.

Haznedar, B. (2010). Transfer at the syntax-pragmatics interface: pronominal subjects in bilingual Turkish. Second Language Research, 26(3), 355-378.

Holton, D., Mackridge, P., Philippaki-Warburton, I., \& Spyropoulos, V. (2012, second edition). Greek: A Comprehensive Grammar. London \& New York: Routledge.

Kerslake, C. (1987). Noun Phrase Deletion and Pronominalization in Turkish. In H. E. Boeschoten \& L. T. Verhoeven (Eds.), Studies on Modern Turkish: Proceedings of the 3rd Conference on Turkish Linguistics (pp. 91-104). Tilburg: Tilburg University Press.

Kornfilt, J. (1987). Beyond Binding Conditions: The Case of Turkish. In H. E. Boeschoten \& L. T. Verhoeven (Eds.), Studies on Modern Turkish: Proceedings of the 3rd Conference on Turkish Linguistics (pp. 105-120). Tilburg: Tilburg University Press.

Kornfilt, J. (1997). Turkish. London: Routledge.

Lomba, A. (2006). Little Red Riding Hood. New-York: McGraw-Hill.

Montrul, S., \& Rodríguez-Louro, C. (2006). Beyond the Syntax of the Null Subject Parameter: A Look at the Discourse-Pragmatic Distribution of Null and Overt Subjects by L2 Learners of Spanish. In V. Torrens \& L. Escobar (Eds.) The Acquisition of Syntax in Romance Languages (pp. 401-418). Amsterdam: John Benjamins.

Özsoy, S. (1987). The Null Subject Parameter in Turkish. In H. Boeschoten \& L. Verhoeven (Eds.), Studies on Modern Turkish: Proceedings of the 3rd Conference on Turkish Linguistics (pp. 82-90). Tilburg: Tilburg University Press.

Özsoy, S. (1992). Türkçede Eşgönderge Örüntüsü. Dilbilim Araştırmaları, 77-85.

Özsoy, S. (1999). Türkçe/Turkish. İstanbul: Boğaziçi Üniversitesi Yayınları.

Öztürk, B. (2005). Case, Referentiality, and Phrase Structure. Amsterdam: John Benjamins Publishing Company.

Pérez-Leroux, A. T., \& Glass, W. R. (1997). OPC effects on the L2 acquisition of Spanish. In A. T. Pérez-Leroux \& W. R. Glass (Eds.), Contemporary perspectives on the acquisition of Spanish (pp. 149-165). Somerville, Mass.: Cascadilla Press.

Pérez-Leroux, A. T., \& Glass, W. R. (1999). Null anaphora in Spanish second language acquisition: probabilistic versus generative approaches. Second Language Research, 15(2), 220-249.

Prince, E. (1985). Fancy syntax and shared knowledge. Journal of Pragmatics, 9, 65-81.

Quesada, M., \& Blackwell, S. E. (2009). The L2 Acquisition of Null and Overt Spanish Subject Pronouns: A Pragmatic Approach. In J. Collentine, M. Garcia, B. Lafford \& F. Marcos Marín (Eds.), Selected Proceedings of the 11th Hispanic Linguistics Symposium (pp. 117-130). Somerville, MA: Cascadilla Proceedings Project. 
Quesada, M. (2015). The L2 Acquisition of Spanish Subjects: Multiple Perspectives. De Gruyter Mouton.

Ruhi, Ş. (1996). Zero NP Anaphora versus Full NP Anaphora in Turkish. In A. Konrot (Ed.), Modern Studies in Turkish Linguistics: Proceedings of the 6th International Conference on Turkish Linguistics, 12-14 August 1992 (pp. 105-116) Eskişehir: Anadolu University.

Serratrice, L., Sorace, A., \& Paoli, S. (2004). Crosslinguistic influence at the syntax-pragmatics interface: Subjects and objects in English-Italian bilingual and monolingual acquisition. Bilingualism: Language and Cognition, 7, 183-205.

Slabakova, R., \& Ivanov, I. (2011). A more careful look at the syntax-pragmatics interface. Lingua, 121, 637-651. DOI: 10.1016/j.lingua.2010.05.003

Sorace, A. (2003). Near-nativeness. In M. Long and C. Doughty (Eds.), Handbook of Second Language Acquisition (pp.130-152). Oxford: Blackwell.

Sorace, A., \& Filiaci, F. (2006). Anaphora resolution in near-native speakers of Italian. Second Language Research, 22, 339-368.

Sorace, A., \& Serratrice, L. (2009). Internal and external interfaces in bilingual language development: beyond structural overlap. International Journal of Bilingualism, 13, 195-210.

Taylan, E.E. (1986). Pronominal versus Zero Representation of Anaphora in Turkish. In D. Slobin \& K. Zimmer (Eds.), Studies in Turkish Linguistics (pp. 209-231.). Amsterdam: John Benjamins Publishing.

Tsimpli, I., Sorace, A., Heycock, C., \& Filiaci, F. (2004). First language attrition and syntactic subjects: A study of Greek and Italian near-native speakers of English". International Journal of Bilingualism, $8(3), 257-277$.

Tsimpli, I.M., \& Papadopoulou, D. (2006). Aspect and argument realization: A study on antecedentless null objects in Greek. Lingua, 116, 1595-1615.

Tsimpli, I.-M., \& Sorace, A. (2006). Differentiating interfaces: L2 performance in syntax-semantics and syntax-discourse phenomena. In D. Bamman, T. Magnitskaia \& C. Zaller (Eds.), Proceedings of the 30th Annual BUCLD (pp. 653-664). Somerville, MA: Cascadilla Press.

Turan, Ümit D. (1995). Null vs. Overt Subjects in Turkish Discourse: A Centering Analysis (Unpublished doctoral dissertation). University of Pennsylvania.

Turan, Ü. D. (1998). Zero Object Arguments and referentiality in Turkish. In L. Johanson (Ed.), The Mainz Meeting, Proceedings of the Seventh International Conference on Turkish Linguistics (pp. 154-182). Harrassowitz Verlag - Wiesbaden.

Turan, Ü. D. (2000). The properties of null objects in Turkish. Anadolu Üniversitesi Sosyal Bilimler Dergisi 1(2), 131-144.

White, L. (2011). Second language acquisition at the interfaces. Lingua, 121, 577-590. DOI:10.1016/j.lingua.2010.05.005 


\section{Türkçeyi 2. dil olarak edinen Yunan konuşucuların sözlü söylemde açık ve boş 1. kişi özne kullanımını yöneten söylem edimbilimsel kuralları edinimi}

\section{$\ddot{O} \mathbf{z}$}

Her dil boş üyelerin kullanımına izin veren bazı sözdizimsel, anlambilimsel ve söylem-edimbilimsel etkenlere duyarlıdır. İkinci dil araştırmacıları da söylem koşullarına bağlı olarak belirli bir gönderim öğesinin seçimini yöneten çeşitli söylem-edimbilimsel etkenlerin ikinci dilde edinimini araştırmaktadır. Bu çalışmalar, açık ve boş üye dağılımının sözdizim-söylem arayüzünde söylem-edimbilimsel etkenlerle yönetildiği durumlarda 2. dil edinenlerin zorluklar yaşadıklarını; ancak sadece sözdizimsel etkenlerle yönetildiği durumlarda bu zorlukları yaşamadıklarını ortaya çıkarmaktadır. Bu saptamadan hareketle, bu çalışmanın amacı, Türkçe sözlü söylemde 1 . kişi için kullanılan boş özne ve açık öznenin kullanımlarını yöneten söylem-edimbilimsel etkenlerin, Türkçeyi ikinci dil olarak edinenlerde edinim durumunu araştırmaktır.

Türkçede, büyük söylem parçaları dikkate alındığında, boş ve açık üyeler aynı dağılımsal özellikleri göstermemektedir. Söylem düzeyinde bu dağılımı etkileyen söylem-edimbilimsel etkenler bulunmaktadır (Kerslake, 1987; Ruhi, 1996; Turan, 1995; Çeltek ve Oktar, 2014, Çeltek Kaili, 2017). Bu çalışmada, sözlü söylemde boş ve açık özne kullanımını yöneten söylem-edimbilimsel kuralların belirlenmesinde 5 söylemedimbilimsel kural temel alınmıştır: Göndergenin belirginliği, Değişen odak, Karşıtsal odak, Edimsel değer, Ara bilgi. Bu söylem-edimbilimsel kuralların Türkçeyi ikinci dil olarak edinenler tarafından edinim durumunu ortaya çıkarabilmek üzere, çalışmada, çözümlemeler, Türkçeyi 2. dil olarak öğrenen yetişkin 10 Yunan konuşucu (C1 düzeyi) ve kontrol grubu olarak da 10 Türkçe anadil konuşucusundan elde edilen sözlü anlatı metinleri üzerinde yapılmaktadır. Bu sözlü metinler 3 ayrı görev uygulanarak (bir kişinin kişisel ve fiziksel özelliklerinin tarif edilmesi, resimler yoluyla bir masalın anlatımı ve katılımcının geleceğine yönelik profesyonel planlarını anlatımı) elde edilmiştir. Çözümlemeler sonucunda Türkçeyi ikinci dil olarak edinen katılımcıların sözlü anlatı metinlerinde 1. kişi için kullanılan boş ve açık özneleri yöneten söylem-edimbilimsel kuralları Türkçe anadil konuşucuları ile benzer biçimlerde kullandıkları saptanmıştır.

Anahtar sözcükler: boş üye; açık üye; söylem-edimbilimsel etkenler; Türkçenin ikinci dil olarak edinimi; söylem edinimi

\section{AUTHOR BIODATA}

Aytaç Çeltek holds an MA and a Ph.D. in General Linguistics from Dokuz Eylül University in İzmir, Turkey. Her Ph.D. thesis focused on Zero Anaphora in Turkish (2008). She has worked as a research assistant at the Department of Linguistics at Dokuz Eylül University (2001-2007) and as an adjunct lecturer of Turkish language at the University of the Aegean, the Department of Mediterranean Studies (Greece) (2008-2013). Since 2014, she has been working as a faculty member at Kırıkkale University, Department of Western Languages and Literatures, Division of English Translation, and Interpretation. She has also been giving both graduate and undergraduate courses at Ankara University. She is the author of several articles on zero anaphora in Turkish, the teaching of Turkish to foreigners and the linguistic repertoire of the Turkish-Greek bilingual community of Rhodes. 